Original Research Paper

\title{
Upaya Meningkatkan Minat Belajar Siswa di Masa Pandemi Covid-19 Melalui Pembelajaran Door to Door di Kelurahan Kendo Kecamatan Raba Kota Bima
}

\author{
Mahrus $^{1}$, Arif Safrillah ${ }^{1}$, Wiranting Ayuningtias ${ }^{1}$ Moh. Nurul Ainun ${ }^{2}$, Taufikurahman ${ }^{3 *}$, Elsa Firda \\ Ramadan $^{3}$ \\ ${ }^{1}$ Program Studi Pendidikan Biologi, Fakultas Keguruan dan Ilmu Pendidikan, Universitas Mataram, Mataram, Indonesia; \\ 2 Program Studi Pendidikan Bahasa dan Sastra Indonesia, Fakultas Keguruan dan Ilmu Pendidikan, Universitas Mataram, \\ Mataram, Indonesia; \\ 3 Program Studi Pendidikan Pancasila dan Kewarganegaraan, Fakultas Keguruan dan Ilmu Pendidikan, Universitas \\ Mataram, Mataram, Indonesia;
}

https://doi.org/10.29303/jpmpi.v3i2.961

Sitasi: Mahrus., Safrillah, A., Ayuningtias, W., Ainun, M. N., Taufikurahman \& Ramdan, E. F. (2021). Upaya Meningkatkan Minat Belajar Siswa di Masa Pandemi Covid-19 Melalui Pembelajaran Door to Door di Kelurahan Kendo Kecamatan Raba Kota Bima. Jurnal Pengabdian Magister Pendidikan IPA, 4(3)

\section{Article history}

Received: 30 Agustus 2021

Revised: 13 September 2021

Accepted: 16 September 2021

*Corresponding Author:

Mahrus, Program Studi Pendidikan Biologi, Fakultas Keguruan dan Ilmu Pendidikan, Universitas Mataram, Mataram, Indonesia.

Email: $\underline{\text { mahrus@unram.ac.id }}$

\begin{abstract}
Selama masa pandemi Covid-19 sekolah-sekolah ditutup sehingga tidak memungkinkan kegiatan belajar mengajar berlangsung secara normal. Kota Bima, Provinsi Nusa Tenggara Barat (NTB) merupakan wilayah yang berzona merah, sehingga pembelajaran yang biasanya dilakukan secara tatap muka di sekolah dialihkan menjadi pembelajaran daring (online). Pelaksanaan pembelajaran daring di Kelurahan Kendo Kecamatan Raba Kota Bima tidak berjalan lancar karena mengalami gangguan jaringan internet di beberapa lokasi. Dampak dari tidak stabilnya jaringan internet sebagai pendukung pembelajaran daring di masa Pandemi Covid-19 adalah minat belajar siswa rendah. Untuk itu, mahasiswa Kuliah Kerja Nyata (KKN) Terpadu Universitas Mataram memilih lokasi tersebut untuk melaksanakan program kegiatan KKN selama dari tanggal 1 Desember 2020 sampai 11 januari 2021 dengan tema "Mengajar di desa dengan menggunakan metode pembelajaran door to door". Program kegiatan KKN ini bertujuan untuk meningkatkan minat belajar siswa di masa pandemi Covid-19 melalui pembelajaran menggunakan metode door to door. Pelaksanaan kegiatan ini terdiri dari 3 tahapan yaitu tahap persiapan, tahap pelaksanaan, dan evaluasi. Hasil kegiatan menunjukkan bahwa pembelajaran menggunakan metode door to door di masa pandemi Covid-19 ini dapat meningkatkan minat dan hasil belajar siswa di Kelurahan Kendo Kecamatan Raba Kota Bima.
\end{abstract}

Keywords: Kelurahan Kendo; Minat belajar; Hasil belajar; Covid-19; Door to door.

\section{Pendahuluan}

Kelurahan Kendo Kecamatan Raba Kota Bima Provinsi NTB merupakan salah satu lokasi pelaksanaan Kuliah Kerja Nyata (KKN) Terpadu Universitas Mataram periode 1 Desember 2020 sampai 11 januari 2021. Kelurahan Kendo memiliki luas $17,2 \mathrm{~km}^{2}$ sebelum pemekaran dan setelah pemekaran memiliki luas $9,08 \mathrm{~km}^{2}$ dengan 12 meter ketinggian di atas permukaan laut. Wilayah
Kelurahan Kendo beriklim tropis, memiliki curah hujan rata-rata $87,8 \mathrm{~mm} /$ bulan. Mata pencaharian masyarakat Kendo mayoritas sebagai Petani sekitar $80 \%$ dan 20\% sebagai PNS.

Kota Bima yang sebelumnya menyandang status zona oranye atau risiko sedang penularan Covid-19 kembali menjadi zona merah atau risiko tinggi. Kota Bima menjadi satu-satunya wilayah di Provinsi NTB yang menyandang status zona merah setelah terjadi penambahan kasus Covid-19 dan kematian di Kota Bima (Kompas, 2020). 
Pandemi Corona Virus Disease (Covid-19) saat ini telah menyebar di seluruh dunia dan Pemerintah menerapkan Pembatasan Sosial Berskala Besar (PSBB) yang menyebabkan ditutupnya sekolah dan dimulainya kegiatan pembelajaran di rumah. Pelaksanaan kegiatan belajar di rumah dengan sistem pembelajaran daring ini didasarkan Surat Edaran Mendikbud No. 36962/MPK.A/HK/2020 tentang pembelajaran secara daring dalam rangka pencegahan penyebaran Covid-19 yang dialamatkan kepada Seluruh Pemimpin Perguruan Tinggi Negeri/Swasta, Seluruh Kepala Lembaga Layanan Pendidikan Tinggi, Seluruh Kepala Dinas Pendidikan Provinsi, Seluruh Kepala Dinas Pendidikan Kabupaten/Kota, dan Seluruh Kepala Unit Pelaksana Teknis Kementerian Pendidikan dan Kebudayaan.

Prinsip dari tindakan pencegahan penyebaran Covid-19 tersebut adalah menghendaki agar masyarakat untuk tetap berada di rumah, bekerja, belajar dan beribadah di rumah. Salah satu sektor yang terdampak dari pandemi covid-19 ini adalah dunia Pendidikan (Purwanto dkk, 2020). Kondisi ini menyebabkan lembaga pendidikan baik formal, informal dan nonformal menutup pembelajaran tatap muka dan beralih dengan pembelajaran daring. Peralihan pembelajaran dari yang semula tatap muka menjadi pembelajaran daring, juga memunculkan banyak hambatan bagi guru terutama yang terkait dengan jaringan internet yang tidak lancar.

Semenjak sistem pembelajaran daring diterapkan, kebanyakan siswa mengeluh karena tugas yang semakin banyak sedangkan siswa tidak paham terkait materi yang diberikan. Peristiwa tersebut mengakibatkan banyaknya orang tua murid mengalami kesulitan dalam melakukan bimbingan kepada putra putrinya.

Salah satu wilayah yang mengalami kendala jaringan internet adalah Kelurahan Kendo Kecamatan Raba Kota Bima, sehingga tidak memungkinkan dilakukan pembelajaran secara daring. Untuk itu, mahasiswa KKN Universitas Mataram memilih tempat tersebut untuk melakukan KKN dengan tema "Mengajar di desa dengan menggunakan metode pembelajaran door to door". Tujuan penerapan model pembelajaran door to door adalah untuk meningkatkan minat belajar siswa di masa pandemi Covid-19. KKN Terpadu Covid-19 ini dirancang khusus sebagai solusi pelaksanaan KKN selama pandemi Covid-19 secara kelompok dengan jumlah anggota kelompok tidak lebih dari 10 orang siswa dan tetap diwajibkan untuk mengikuti protokol kesehatan seperti menggunakan masker, mencuci tangan, dan menjaga jarak.

\section{Metode}

\section{Tempat dan waktu pelaksanaan}

Waktu dan tempat kegiatan pelaksanaan pembelajaran door to door berlangsung selama 45 hari periode $\mathrm{KKN}$ terhitung mulai dari tanggal 1 Desember 2020 - 11 Januari 2021 bertempat di Kelurahan Kendo Kecamatan Raba Kota Bima.

\section{Bahan}

Bahan yang dibutuhkan di dalam pelaksanaan penerapan model pembelajaran door to door adalah: Papan tulis, Spidol, Kertas hvs, Sketsa gambar hewan, buah dan tumbuhan, Pensil dan penghapus, Pulpen, Krayon/pensil warna, dan lain-lainnya.

\section{Metode}

Metode pembelajaran yang digunakan adalah door-to-door, merupakan metode dimana seorang guru mengunjungi kediaman siswa untuk penyampaian suatu pembelajaran. Metode doorto-door ini merupakan metode pembelajaran tambahan di luar jam sekolah seperti les. Perbedaannya adalah guru telah mempersiapkan materi yang akan dipelajari, sedangkan metode les siswa bertanya tentang materi apa yang tidak dimengerti saat di sekolah. Pelaksanan model pembelajaran door-to-door terdiri dari tiga tahapan, yaitu:

\section{Tahap persiapan}

Pada tahap persiapan ini mahasiswa peserta KKN menyiapkan berbagai macam media dan alat peraga secara kreatif dan inovatif sehingga dapat menunjang kegiatan pembelajaran dan meningkatkan minat belajar siswa. Media dan alat peraga yang disiapkan sebagai berikut: sketsa gambar hewan, buah, tumbuhan, pensil, penghapus, pulpen, krayon/ pensil warna, dan lain-lain.

\section{Tahap pelaksanaan}

Tahap pelaksanaan terdiri atas satu kegiatan inti dan satu kegiatan tambahan. Kegiatan inti adalah mengajar di desa yang secara khusus ditujukan untuk peningkatan minat belajar siswa di masa pandemi melalui pembelajaran door 
to door (Gambar 1), sedangkan kegiatan tambahannya yaitu kegiatan baca tulis Al-qur'an (Gambar 2).

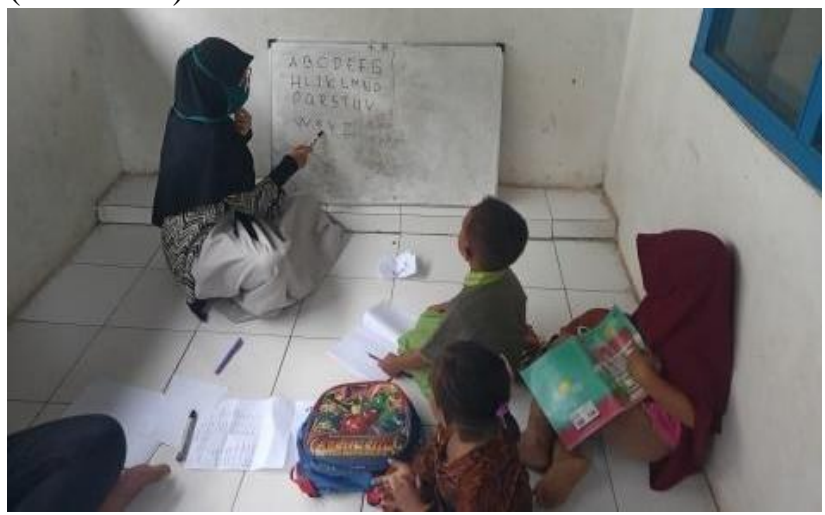

Gambar 1. Kegiatan belajar siswa

Sasaran dari kegiatan inti adalah anakanak usia sekolah, sedangkan sasaran untuk kegiatan tambahannya adalah semua kalangan yang ingin belajar baca tulis Al-quran.

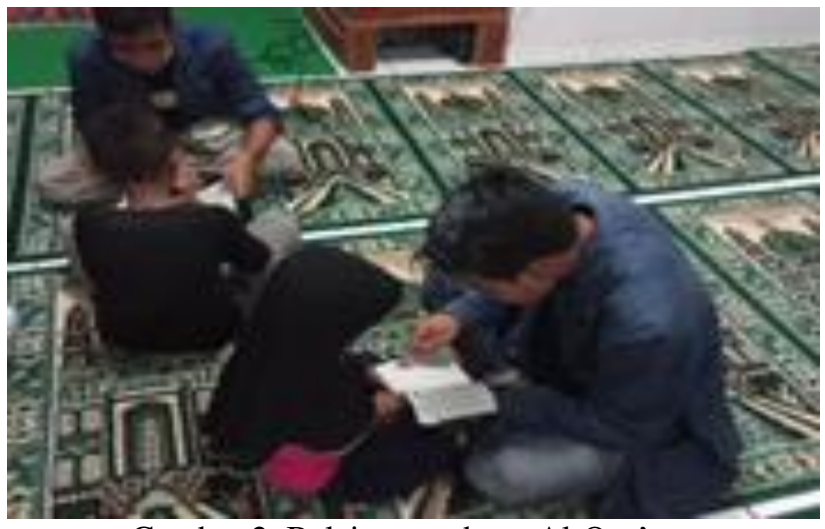

Gambar 2. Belajar membaca Al-Qur’an

Tahap pelaksanaan untuk kegiatan pertama dilakukan dengan cara melaksanakan sosialisasi terkait program kerja mengajar di desa kepada Lurah, ketua Karang Taruna, Pembina TPQ sekaligus ketua remaja masjid, dan ketuaketua RT di kelurahan Kendo Kecamatan Raba Kota Bima. Setelah mendapatkan persetujuan, maka peserta KKN dan pembina organisasi menentukkan jadwal kegiatan mengajar di desa yang dijadikan pedoman dalam melaksanakan program KKN. Waktu kegiatan inti yang telah disepakati dilakukan pada sore hari pada jam 15:30-18:10. Sedangkan untuk program tambahannya dilakukan pada malam hari (setelah magrib) sampai jam 20:30 selama 6 pekan (45 hari).

\section{Tahap evaluasi}

Tahap evaluasi dilakukan sebagai tolak ukur keberhasilan suatu program yang sudah diterapkan, meliputi:

a. Pada pekan pertama, anak-anak di kelurahan kendo kurang berminat untuk belajar, ini terbukti ketika kami berkeliling dari rumah ke rumah (door to door) untuk mengajak mereka belajar bersama, mereka lebih memilih untuk bermain daripada belajar bersama. Namun, tim yang tergabung dalam KKN mendapat dukungan dari para orang tua, sehingga anakanak mau belajar bersama kami.

b. Pada pekan kedua, anak-anak di kelurahan kendo menunjukan peningkatan minat belajar mereka, hal ini terbukti ketika tim berkeliling dari rumah ke rumah (door to door) untuk mengajak mereka belajar bersama. Mereka merespon ajakan tim dengan senang hati untuk ikut belajar bersama kami.

c. Pada pekan tiga sampai pekan ke enam, anakanak di kelurahan kendo sangat antusias untuk belajar yang ditunjukkan dengan adanya sebagian anak-anak sengaja menunggu tim di tempat yang dijadwalkan untuk belajar bersama. Bahkan ada beberapa anak sengaja datang ke posko KKN untuk mengajak kami belajar bersama.

\section{Hasil dan Pembahasan}

\section{Minat belajar}

Pada mulanya sebagian besar dari kalangan anak-anak maupun remaja memiliki minat belajar rendah selama pandemi covid -19 . Melihat persoalan yang cukup serius ini, mahasiswa KKN Unram terjun langsung ke lokasi untuk membantu pemerintah desa serta masyarakat setempat untuk melakukan kegiatan pembelajaran untuk mengejar ketertinggalan pelajaran anak-anak. Mahasiswa KKN mengajak secara langsung siswa untuk melakukan belajar bersama, agar tidak lupa materi pelajaran yang telah didapatkan selama belajar di sekolah dengan menerapkan model pembelajaran menggunakan metode door to door.

Rata-rata alasan yang mereka sampaikan kepada mahasiswa peserta KKN adalah ketika sedang melakukan pembelajaran jarak jauh mereka sulit untuk fokus saat guru sedang menjelaskan. Alasan lainnya sering terjadi kendala jaringan. Saat guru menjelaskan mereka tidak dapat menerima 
materi dengan sempurna, dengan demikian para siswa tetap merasakan keresahan meskipun telah disediakannya kuota internet gratis. Penerapan metode pembelajaran door-to-door di Kelurahan Kendo Kecamatan Raba ini ternyata dapat meningkatkan minat belajar siswa di masa pandemi covid-19. Metode pembelajaran ini mampu menyelesaikan satu permasalah belajar siswa yaitu minat belajar siswa semakin meningkat, diikuti dengan peningkatan hasil belajar siswa. Permasalahan ini juga dipertegas oleh Mutiara \& Sobandi (2018), permasalahan utama yang sering terjadi terutama dalam kegiatan belajar mengajar yang berlangsung di sekolah adalah minat belajar siswa yang tidak sesuai dengan harapan.

Selanjutnya dikatakan bahwa sekolah sebagai lembaga formal yang memiliki fungsi tersendiri dan strategis sebab sekolah bertujuan untuk mempersiapkan masa depan siswa. Dalam hubungan ini guru harus selalu berusaha membangkitkan minat siswa agar menciptakan pembelajaran menyenangkan, sehingga siswa dapat mencapai hasil belajar yang baik. Guru perlu membangkitkan minat belajar siswa agar dapat bergairah untuk menerima pelajaran, menyadarkan siswa agar terlibat langsung dalam pembelajaran, belajar dengan menyenangkan dan dapat menggunakan berbagai metode, strategi, teknik dan pendekatan pembelajaran yang menyenangkan (Simbolon, 2014).

Selain faktor minat, faktor motivasi belajar siswa juga memberikan pengaruh secara simultan terhadap hasil belajar, sebab kedua faktor tersebut akan menimbulkan keingintahuan dan kesenangan untuk terus belajar. Motivasi merupakan suatu kekuatan yang terdapat dalam diri individu, yang menyebabkan individu tersebut bertindak atau berbuat (Hamzah, 2008). Minat dan motivasi belajar siswa akan menimbulkan keingintahuan dan kesenangan untuk terus belajar. Septiani (2016) melaporkan hasil penelitiannya bahwa keingintahuan dan kesenangan belajar itu bisa didapatkan dari ilmu pengetahuan yang diajarkan dan cara guru menyampaikannya. Jika bahan pelajaran dan cara guru menyampaikan pelajaran tidak sesuai dengan minat siswa, maka siswa yang bersangkutan tidak akan belajar dengan baik, karena tidak ada daya tarik (motivasi) bagi siswa itu sendiri.

Untuk membangkitkan motivasi belajar siswa, banyak hal yang perlu dilakukan guru, salah satunya adalah menerapkan program percepatan belajar (akselerasi) seperti yang dilaporkan oleh Muklis (2015) bahwa motivasi belajar siswa dipengaruhi oleh implementasi program percepatan belajar sebesar $96 \%$. Hasil penelitian ini dapat dijadikan sebagai acuan bagi guru di dalam memelihara dan menumbuhkan motivasi belajar siswa secara terus menerus. Untuk itu, para siswa tersebut penting diberikan bimbingan belajar secara khusus pada setiap materi pelajaran yang dirasakan sulit. Model bimbingan belajar yang diterapkan pada kegiatan pembelajaran di lokasi KKN mirip dengan yang dilaporkan oleh Rozak dkk. (2018).

Dari urain ini, guru harus mampu memunculkan dorongan dari dalam diri siswa pada saat pembelajaran berlangsung misalnya guru sedapat mungkin mengaitkan pembelajaran dengan kebutuhan siswa. Faktor yang tidak kalah pentingnya juga adalah keluarga, sebab keluarga merupakan pusat pendidikan yang pertama dan utama. Keterlibatan orang tua sudah sewajarnya dapat memelihara dan membimbing anak dengan penuh kasih sayang untuk meraih masa depan yang lebih baik.

\section{Pembelajaran door to door}

Pelaksanaan metode pembelajaran door-todoor menuntut seorang guru bekerja extra karena harus mengunjungi kediaman siswa untuk melaksanakan kegiatan pembelajaran. Metode ini seperti metode pembelajaran tambahan di luar sekolah seperti les.

Metode door-to-door dinilai lebih efektif dibandingkan metode pembelajaran berbasis daring, dengan alasan siswa tidak memerlukan koneksi internet. Selain itu interaksi secara langsung antara guru dan siswa menghasilkan pemahaman materi pelajaran lebih mudah dipahami siswa. Guru juga dapat dengan mudah mencari kelemahankelemahan siswa yang terkait dengan materi-materi yang diajarkan. Dalam pelaksanaan pembelajaran ini juga para siswa dengan mudah dapat bertanya langsung guru.

Selain kelebihan yang dimiliki oleh metode pembelajaran door to door, metode ini a memiliki kelemahan seperti waktu yang terbatas akibat jumlah murid yang banyak. Pada kegiatan ini, tim KKN yang bertugas sebagai guru menganjurkan untuk mengurangi waktu penyampaian materi sekitar 10-15 menit tiap siswa dan cukup menggunakan waktu sekitar 5-10 siswa per harinya 
dengan tetap menjalankan protokol kesehatan (Gambar 1).

Metode ini efektif untuk daerah-daerah yang kesulitan dalam mengakses jaringan internet. Rohmawati (2015) menyatakan efektivitas pembelajaran merupakan ukuran keberhasilan dari suatu proses interaksi antar siswa dengan siswa maupun antar siswa dengan guru untuk mencapai tujuan pembelajaran.

Respon balik yang diperlihatkan oleh siswa dapat berupa bahasa verbal maupun nonverbal. Ristianti (2017) menyatakan bahwa pesan saat bimbingan diusahakan berupa ajaran atau didikan yang mampu membangkitkan rasa ingin tahu siswa sehingga siswa akan terbiasa belajar. Berdasarkan hasil yang didapatkan pada kegiatan $\mathrm{KKN}$ ini metode pemebelajaran door-to-door cukup ampuh dalam mengatasi kesulitan belajar siswa sekolah dasar di lokasi KKN.

\section{Kesimpulan}

Berdasarkan permasalahan dan pembahasan hasil kegiatan pembelajaran yang dilakukan selama periode KKN dapat disimpulkan bahwa model pembelajaran menggunakan metode door-to-door yang diterapkan pada pelaksanaan KKN di Kelurahan Kendo Kecamatan Raba Kota Bima dapat berfungsi dengan baik. Keberhasilan dapat dilihat dari peningkatan minat belajar siswa dari minggu ke minggu. Pada pekan pertama minat belajar siswa sangat rendah sekali, sehingga ada kesulitan tersendiri untuk mengajak para siswa melakukan kegiatan belajar, tapi dengan dibantu oleh orang tua mereka, akhirnya anakanak yang berada di Kelurahan Kendo memiliki minat untuk belajar bersama. Selanjutnya pada pekan kedua, minat belajar siswa bukan lagi menjadi persoalan, begitupun dengan pekan-pekan selanjutnya bahkan mereka sengaja datang ke posko KKN untuk belajar bersama dengan menyampaikan kesulitannya pada materi pelajaran yang sudah diberikan.

\section{Ucapan Terima Kasih}

Pelaksanaan program kegiatan mahasiswa Kuliah Kerja Nyata (KKN) Terpadu Universitas Mataram dengan judul Upaya Meningkatkan Minat Belajar Siswa Di Masa Pandemi Covid-19 Melalui Pembelajaran Door To Door di Kelurahan Kendo
Kecamatan Raba Kota Bima berjalan lancar atas dukungan banyak pihak. Penulis mengucapkan terima kasih kepada yang terhormat Rektor Universitas Mataram, Ketua LPPM Universitas Mataram, Kepala Dinas Pendidikan dan Kebudayaan Kota Bima beserta jajarannya, Lurah Kendo, Tokoh Masyarakat, Orang Tua Murid, dan semua pihak yang telah memberikan dukungan pada kegiatan tersebut.

\section{Daftar Pustaka}

Hamzah, B. U. (2008). Teori motivasi dan pengukurannya. Jakarta: Bumi Aksara.

Kompas.com. (2020). Kota Bima Berubah dari Zona Oranye ke Merah Penularan Covid-19, Satusatunya

NTB. https://regional.kompas.com/read/2020/1

1/18/15010961/kota-bima-berubah-dari-zonaoranye-ke-merah-penularan-covid-19-satusatunya?page $=$ all.

Muklis, M. (2015). Pengaruh implementasi program percepatan belajar (akselerasi) terhadap motivasi belajar siswa pada mata pelajaran Pendidikan Agama Islam (PAI) di MTS. Negeri Ponorogo (Doctoral dissertation, Universitas Muhammadiyah Ponorogo).

Mutiara, N. U., \& Sobandi, A. (2018). Iklim Sekolah sebagai Determinan Minat Belajar Siswa (School Climate as Determinant Students Learning Interest). Jurnal Pendidikan Manajemen Perkantoran, 3(1), 218-225.

Purwanto, Agus. 2016. Peningkatan Aktivitas dan Hasil Belajar Siswa Pada Mata Pelajaran Ipa dengan menggunakan Metode Examples Non Examples Di Kelas VII SMP 5 Kudus Semester II Tahun Pelajaran 2014/2015. Jurnal Profesi Keguruan. 2(1). 36-41.

Ristianti \& Dina, H. (2017). Analisis Hubungan Interpersonal Mahasiswa Terhadap Dosen Dalam Proses Bimbingan Skripsi (Studi pada Mahasiswa Semester VIII Jurusan Tarbiyah STAIN Curup). Islamic Counseling: Jurnal Bimbingan Konseling Islam, 25-40.

Rohmawati, A. (2015). Efektivitas pembelajaran. Jurnal Pendidikan Usia Dini, 9(1), 15-32.

Rozak, A., Fathurrochman, I., \& Ristianti, D. H. (2018). Analisis Pelaksanaan Bimbingan Belajar dalam Mengatasi Kesulitan Belajar Siswa. JOEAI: Journal of Education and Instruction, 1(1), 1020. 
Septiani, N. (2016). Pengaruh minat dan motivasi belajar terhadap hasil belajar siswa kelas $v$ SDN gugus werkudoro kecamatan Tegal Timur kota Tegal. Skripsi, Universitas Negeri Semarang.

Simbolon, N. (2014). Faktor-faktor yang mempengaruhi minat belajar peserta didik. Elementary School Journal Pgsd Fip Unimed, 1(2). 